\title{
Biochemical Tests in Differential Diagnosis of Protein and Calorie Deficiencies
}

\author{
R. G. WHITEHEAD* \\ From the Medical Research Council Infantile Malnutrition Research Unit, Kampala, Uganda
}

Whitehead (1965) recently showed that a measurement of the amount of hydroxyproline excreted in the urine was of value in detecting marginal malnutrition. He also suggested that a simultaneous measurement of the plasma amino acid ratio (Whitehead, 1964) provided a biochemical means of differentiating between malnutrition, in which the primary deficiency was one of protein, and undernutrition due to deprivation of total calories. These tests were developed to be applied to children in nutritional surveys of communities, but it was considered that they might be of diagnostic value in the individual child who is more severely malnourished. In some children a clinical examination is sufficient to distinguish between the two syndromes, but in others the differential diagnosis is not so clear and more objective methods would be valuable, especially if the children are to be the subjects of metabolic studies. The first aim of this investigation was to evaluate the various biochemical tests which may be used to differentiate marasmus from kwashiorkor. The second aim was to use them to try to separate the two types of kwashiorkor seen in the wards of Kampala. In one, the typical clinical signs of kwashiorkor are found, and the hair is pale, silky, and sparse, while in the other the hair is less severely affected and the clinical picture is often complicated by some acute infection.

Picou, Alleyne, Waterlow, and Seakins (1965) and Whitehead (1965) reported that the excretion of hydroxyproline peptides in the urine of children with kwashiorkor was greater at the end of treatment than at the beginning. This indicated that the urinary hydroxyproline index might also provide a useful means of assessing the response of malnourished and undernourished children to treatment.

\footnotetext{
Received December 15, 1966.
}

* Present address: Medical Research Council, Infant Nutrition Research Division, Dunn Laboratory, 5 Shaftesbury Road, Cambridge. 
TABLE I

Biochemical and Anthropometric Measurements in 52 Children Admitted for Treatment of Kwashiorkor and Marasmus

\begin{tabular}{|c|c|c|c|c|c|c|c|c|c|c|}
\hline & & \multicolumn{3}{|c|}{ Pale-haired Kwashiorkor } & \multicolumn{3}{|c|}{ Dark-haired Kwashiorkor } & \multicolumn{3}{|c|}{ Marasmus } \\
\hline & & No. & Mean & SD & No. & Mean & SD & No. & Mean & SD \\
\hline $\begin{array}{l}\text { Weight for age (\% of normal) } \\
\text { Triceps skinfold (mm.) } \\
\text { Serum protein (g./100 mi.) } \\
\text { Serum amino acid ratio . } \\
\text { Blood glucose (mg./100 mi.) } \\
\text { Blood Hb (g./100 ml.) } . \cdot \\
\text { Urinary hydroxyproline index }\end{array}$ & \begin{tabular}{l|}
$\cdots$ \\
$\cdots$ \\
$\cdots$ \\
$\cdots$ \\
$\cdots$ \\
$\cdots$
\end{tabular} & $\begin{array}{l}22 \\
14 \\
22 \\
22 \\
13 \\
22 \\
22\end{array}$ & $\begin{array}{l}72 \\
7 \cdot 6 \\
4 \cdot 7 \\
5 \cdot 7 \\
47 \\
8 \cdot 2 \\
0 \cdot 94\end{array}$ & $\begin{array}{l}15 \\
2 \cdot 2 \\
0 \cdot 7 \\
1 \cdot 7 \\
11 \\
2 \cdot 2 \\
0 \cdot 25\end{array}$ & $\begin{array}{l}14 \\
14 \\
14 \\
14 \\
12 \\
14 \\
14\end{array}$ & $\begin{array}{l}71 \\
6 \cdot 5 \\
4 \cdot 2 \\
5 \cdot 7 \\
58 \\
6 \cdot 7 \\
1 \cdot 7\end{array}$ & $\begin{array}{l}17 \\
2 \cdot 3 \\
0 \cdot 3 \\
2 \cdot 3 \\
13 \\
2 \cdot 2 \\
0 \cdot 7\end{array}$ & $\begin{array}{l}16 \\
12 \\
16 \\
\frac{16}{12} \\
16\end{array}$ & $\begin{array}{l}3 \cdot 49 \\
6 \cdot 3 \\
2 \cdot 2 \\
9 \cdot 2 \\
0 \cdot 8\end{array}$ & $\begin{array}{l}13 \\
1 \cdot 4 \\
0 \cdot 6 \\
0 \cdot 8 \\
\frac{2 \cdot 5}{0 \cdot 31}\end{array}$ \\
\hline
\end{tabular}

TABLE II

Percentage Incidence of Malaria, Sickling, and Worm Infestations in 52 Children Admitted for Treatment of Kwashiorkor and Marasmus

\begin{tabular}{|c|c|c|c|c|c|c|c|c|c|c|}
\hline & & & & & & & & $\begin{array}{l}22 \text { Pale-haired } \\
\text { Kwashiorkor }\end{array}$ & $\begin{array}{l}14 \text { Dark-haired } \\
\text { Kwashiorkor }\end{array}$ & 16 Marasmus \\
\hline $\begin{array}{l}\text { Malaria . . } \\
\text { Sickling test positive } \\
\text { Homozygous sickle cell } \\
\text { Roundworm ... } \\
\text { Severe hookworm } \\
\text { Mild hookworm .. }\end{array}$ & $\begin{array}{l}\ddot{a} \\
\ddot{a n a} \\
\cdots \\
\cdots\end{array}$ & $\begin{array}{l}\ddot{*} \\
\ddot{a} \\
\cdots\end{array}$ & $\begin{array}{l}\cdots \\
\cdots \\
\cdots \\
\cdots\end{array}$ & $\begin{array}{l}\cdots \\
\cdots \\
\cdots \\
\cdots\end{array}$ & $\begin{array}{l}\cdots \\
\cdots \\
\cdots \\
\cdots \\
\cdots\end{array}$ & $\begin{array}{l}\ddot{*} \\
\ddot{*} \\
\cdots \\
\cdots\end{array}$ & $\begin{array}{l}\cdots \\
\cdots \\
\cdots \\
\cdots \\
\cdots\end{array}$ & $\begin{array}{r}14 \\
9 \\
0 \\
0 \\
18 \\
23\end{array}$ & $\begin{array}{r}36 \\
7 \\
0 \\
21 \\
50 \\
0\end{array}$ & $\begin{array}{r}0 \\
19 \\
6 \\
0 \\
0 \\
12\end{array}$ \\
\hline \multicolumn{5}{|c|}{ Mean egg count in infested cases (per g. faeces) } & $\ldots$ & $\ldots$ & $\ldots$ & 3670 & 14,500 & 500 \\
\hline
\end{tabular}

sickling, and for $\mathrm{Hb}$ electrophoresis. A blood film was prepared for routine malarial examination, and serum was separated from the remaining blood. During the first 24 hours after admission two random samples of urine were collected for total hydroxyproline and creatinine determination. A faecal sample was examined for parasites, in particular roundworm and hookworm infestation.

Urinary creatinine was measured by the method of Bonsnes and Taussky (1945), and total hydroxyproline by a semi-automated procedure based on the method of Prockop and Udenfriend (1960). Full details of this procedure will be published elsewhere. The hydroxyproline index was calculated from the following formula (Whitehead, 1965):

$$
\text { Index }=\frac{\text { mmole hydroxyproline } / 1 \text {. }}{(\text { mmole creatinine } / \mathrm{l} \text {.)/kg. body wt. }}
$$

The hydroxyproline indices accepted were the average values for the two random urine samples. The serum amino acid ratio was measured by the method of Whitehead (1964), and the total proteins were determined by a specific gravity method or by a microrefractometer (model 10401, American Optical Company, Buffalo, New York, U.S.A.). Blood glucose was determined by the enzymic method of Marks (1959). $\mathrm{Hb}$ was estimated by the cyanhaemoglobin method (Varley, 1962). The screening test for sickling was the sodium dithionite method, and the homozygous and heterozygous forms were distinguished by paper electro- phoresis (Dacie and Lewis, 1963). No special tests for sickle cell thalassaemia were made because this disease is not met with in East Africa.

\section{Results}

Clinical signs and anthropometric measurements. Tables I and II show the results on admission to the ward for the children suffering from marasmus, kwashiorkor with pale hair, and kwashiorkor with dark hair. The children in the two groups with kwashiorkor were clinically similar among themselves and to those described by Dean and Jelliffe (1960), except that the hair in the first group was sparse and silky, but in the second it was less severely discoloured.

The marasmic children were more below their expected weight for age than either the pale-haired patients with kwashiorkor $(t=5 \cdot 04, p<0 \cdot 001)$ or the dark-haired ones $(t=3 \cdot 87, p<0.001)$, but the deficit in weight of both groups with kwashiorkor was the same. Oedema was equally severe in these two types, but absent in the marasmic cases. The average skinfold thickness was slightly greater in the patients with pale hair than in those with dark, but the difference was not significant. The tendency for these cases to have less subcutaneous fat, together with dark-coloured hair, had led to a 
provisional diagnosis of 'marasmic kwashiorkor' in 7 of the 14 cases. This diagnosis was given to none of the pale-haired children. The skinfold thickness in the marasmic children was very low and significantly different from that found in the pale and dark-haired children suffering from kwashiorkor $(t=6.16, p<0.001)$. It was not possible to measure the severity of the skin lesions but, using a more or less arbitrary scale, 6 of the 22 pale-haired protein-deficient children were classified as having severe skin lesions, but only 1 of the 14 dark-haired ones, and none of those with marasmus.

Biochemical tests. The hydroxyproline indices of the children with pale hair (mean, 0.94 , range $0 \cdot 63-1 \cdot 49$ ) and of those with marasmus (mean 0.85 , range $0 \cdot 50-1 \cdot 40$ ) were both very low and not statistically different from each other $(t=1 \cdot 0$, $p=0.3$ ). The normal value for children of this age is $2 \cdot 9$, range $2 \cdot 0-5 \cdot 0$ (Whitehead, 1965). The hydroxyproline indices of the dark-haired children with kwashiorkor were relatively high (mean 1.70 , range $1 \cdot 15-2 \cdot 80$ ), and significantly different from the children with kwashiorkor and with pale hair $(\mathrm{t}=4 \cdot 12, \mathrm{p}<0.001)$ and from those with marasmus $(t=4.41, p<0.001)$. The mean index for the dark-haired group was, however, significantly lower than the value for normal children $(t=5 \cdot 26$, $\mathrm{p}<0.001$ ).

The total serum protein and amino acid ratios clearly differentiated the children with marasmus from both groups with kwashiorkor. The highest serum protein level was found in the marasmic children and the mean value, $6 \cdot 1$, and the range, $5 \cdot 0-7 \cdot 2$ g. $/ 100 \mathrm{ml}$., differed little from the normal values for children in the age-group 1-12 months (mean 6.3 range $5 \cdot 6-7 \cdot 0 \mathrm{~g} . / 100 \mathrm{ml}$.). The mean total serum protein in the pale-haired children with kwashiorkor was $4 \cdot 7$, range $3 \cdot 8-5 \cdot 4 \mathrm{~g} . / 100 \mathrm{ml}$., which was much lower than in those with marasmus $(t=6.36, p<0.001)$, and lower still in the dark- haired cases (mean $4 \cdot 2$, range $3 \cdot 9-5 \cdot 0 \mathrm{~g} . / 100 \mathrm{ml}$.). The difference between the two types of kwashiorkor was significant $(t=2 \cdot 81, p<0 \cdot 01)$.

The plasma amino acid ratio was raised in both groups with kwashiorkor. The range of values in the dark-haired group was $2 \cdot 6-10 \cdot 0$, and in the pale-haired one $4 \cdot 0-8 \cdot 4$, and the mean in both groups was $5 \cdot 7$. The values were quite different in the marasmic group, range $1 \cdot 1-2 \cdot 9$; the mean $2 \cdot 2$ was only slightly above the mean value reported for European children, 1.5 (Whitehead and Dean, 1964) and successfully treated African children, mean 1.9 (Rutishauser and Whitehead, to be published). The difference between amino acid ratios in the marasmic children and in those with either pale hair or dark hair and kwashiorkor was highly significant $(\mathrm{t}=10.0, \mathrm{p}<0.001$ and $\mathrm{t}=5.34, \mathrm{p}<0.001$, respectively).

The blood glucose levels were lower in the palehaired children with kwashiorkor (mean $47 \mathrm{mg} . / 100$ $\mathrm{ml}$.) than in the dark-haired children (mean, $58 \mathrm{mg}$./ $100 \mathrm{ml}$; $\mathrm{t}=2 \cdot 27, \mathrm{p}<0.05$ ). The children with dark hair were more anaemic than those with pale hair (Hb 6.7 and 8.2 g. $/ 100 \mathrm{ml}$., respectively; $\mathrm{t}=1 \cdot 97, \mathrm{p}=0 \cdot 10-0 \cdot 05)$. The $\mathrm{Hb}$ level in the marasmic children was $9.2 \mathrm{~g}$. $/ 100 \mathrm{ml}$., which was significantly higher than either kwashiorkor group ( $\mathrm{t}=2 \cdot 92, \mathrm{p}<0.01)$, but still below the normal value $(10.8 \mathrm{~g} . / 100 \mathrm{ml}$.) for children of this age (World Health Organization, 1959).

Table II shows some of the reasons why the dark-haired children with kwashiorkor probably had such low $\mathrm{Hb}$ levels. One half of them had severe hookworm infestations and the mean egg count was higher than in the similarly infested cases with pale hair. The incidence of malaria and roundworm infestations was also higher.

Table III shows the mean hydroxyproline indices of 11 of the marasmic children and 17 of the palehaired children with kwashiorkor on admission and during treatment. The index in the cases of kwashiorkor rose gradually during treatment, but

\section{TABLE III}

\section{Changes in Urinary Hydroxyproline Index in Children Being Treated for Kwashiorkor and Marasmus}

\begin{tabular}{|c|c|c|c|c|c|c|}
\hline \multirow{2}{*}{$\begin{array}{c}\text { Day of } \\
\text { Treatment }\end{array}$} & \multicolumn{3}{|c|}{ Kwashiorkor } & \multicolumn{3}{|c|}{ Marasmus } \\
\hline & No. Investigated & Mean Index & SD & No. Investigated & Mean Value & SD \\
\hline $\begin{array}{r}0 \\
4 \\
7 \\
14 \\
21 \\
28 \\
35\end{array}$ & $\begin{array}{l}17 \\
14 \\
16 \\
16 \\
16 \\
11 \\
\end{array}$ & $\begin{array}{c}0.94 \\
1.13 \\
1.33 \\
1.55 \\
1.82 \\
2.30 \\
-\end{array}$ & $\begin{array}{c}0.22 \\
0.30 \\
0.48 \\
0.47 \\
0.70 \\
0.74 \\
-\end{array}$ & $\begin{array}{r}11 \\
6 \\
11 \\
11 \\
11 \\
8 \\
7\end{array}$ & $\begin{array}{l}0 \cdot 79 \\
1 \cdot 00 \\
1 \cdot 13 \\
1 \cdot 13 \\
1 \cdot 13 \\
1 \cdot 25 \\
1 \cdot 46\end{array}$ & $\begin{array}{l}0.36 \\
0.21 \\
0.34 \\
0.32 \\
0.38 \\
0.36 \\
0.43\end{array}$ \\
\hline
\end{tabular}


TABLE IV

Percentage Incidence of Intercurrent Infections Appearing During Treatment in 11 Marasmic Children and 17 Children With Kwashiorkor

\begin{tabular}{|c|c|c|c|c|}
\hline Infection & & & Marasmic & Kwashiorkor \\
\hline 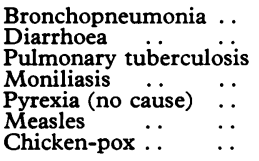 & $\begin{array}{l}\cdots \\
\cdots \\
\cdots \\
\cdots \\
\cdots\end{array}$ & \begin{tabular}{l|}
$\cdots$ \\
$\cdots$ \\
$\cdots$ \\
$\cdots$ \\
$\cdots$ \\
$\cdots$
\end{tabular} & $\begin{array}{r}73 \\
55 \\
18 \\
18 \\
36 \\
9 \\
0\end{array}$ & $\begin{array}{r}0 \\
29 \\
0 \\
0 \\
23 \\
18 \\
6\end{array}$ \\
\hline
\end{tabular}

not so in those with marasmus, for in them the mean index did not rise significantly between days 7 and 35. The incidence of intercurrent infections during treatment however (see Table IV) was greater in the marasmic children than in those with kwashiorkor. Bronchopneumonia, diarrhoea, and pyrexia of unknown origin were the major problems. During the infections, in children with both kwashiorkor and marasmus, the rise in the hydroxyproline index ceased, and in many cases there was a fall. Fig. 1 shows a good example. For the first 6 days the index level remained low, but on the 7 th day there was a sudden rise, which was subsequently followed by an improvement in weight. On day 11 , however, the hydroxyproline index started to fall again, and on day 12 the child developed a temperature and moniliasis was diagnosed. This infection was accompanied by a cessation of growth. The hydroxyproline index rose again after the 14th day, but the child then developed bronchopneumonia, measles, and finally diarrhoea accompanied by a high temperature. All the infections adversely affected the rise in the hydroxyproline index, and in general reduced the rate of growth, though relatively less than the index.

The serum protein and amino acid ratio varied little during the course of treatment of the marasmic children. In the cases of kwashiorkor, however, the serum protein levels rose to $6 \mathrm{~g} . / 100 \mathrm{ml}$. or more during the first two weeks of treatment, and this was not prevented by the infections. The amino acid

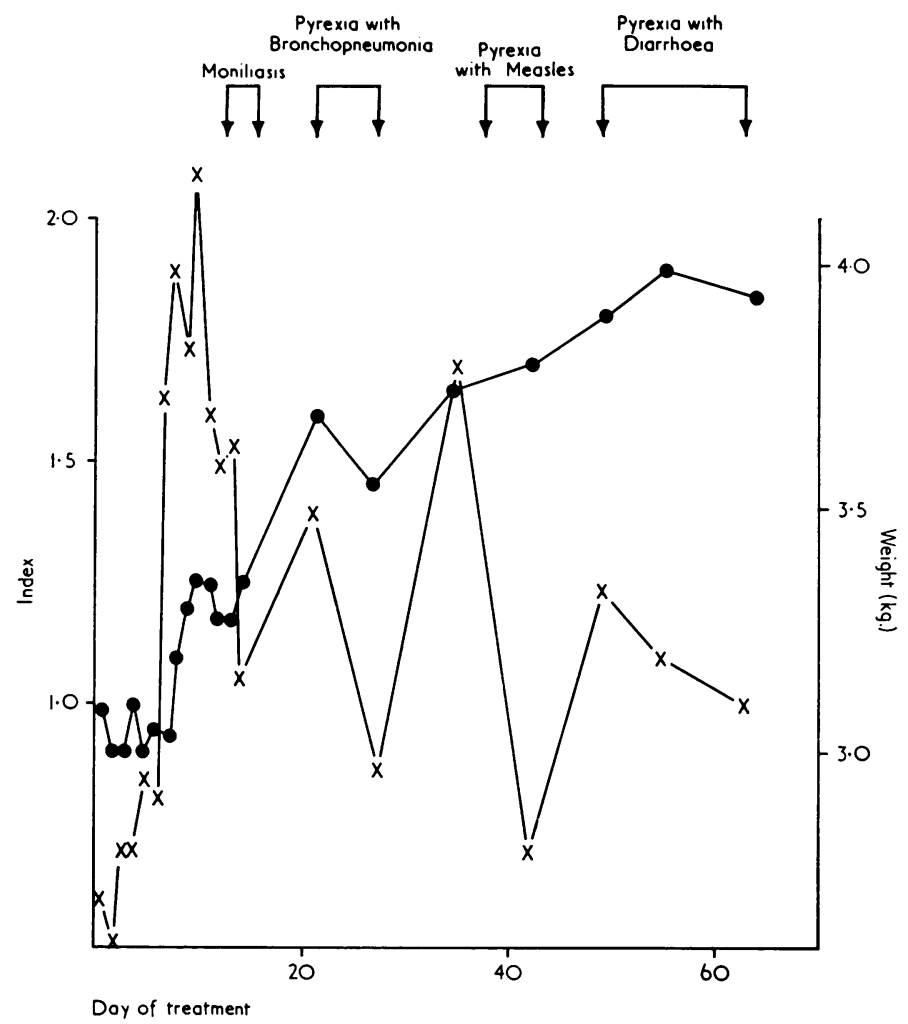

FIG. 1.-Changes in the urinary hydroxyproline index and the body weight during the treatment of a child with nutritional marasmus. The incidence of infection is also shown. 


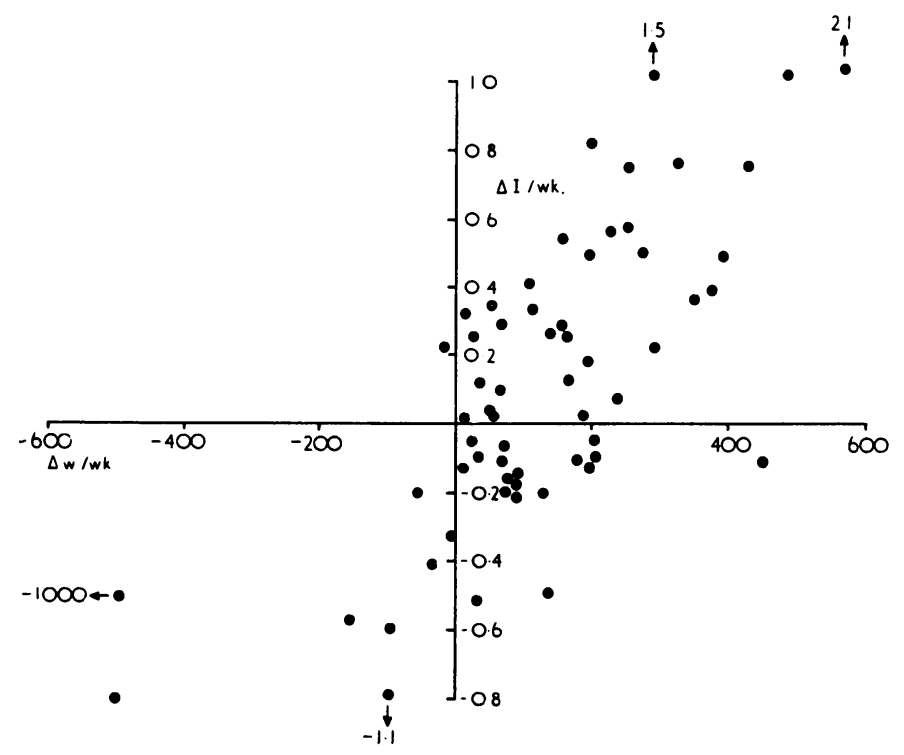

FIG. 2.-The relation between the net increase or decrease in the hydroxyproline index per week $(\triangle I / w k$.$) and the$ corresponding change in body weight $(\triangle W / w k$.$) in 11$ marasmic children.

ratio fell with successful treatment to values usually below $2 \cdot 0$; in one or two cases this was retarded by infection, but the measurement was not so sensitive as the hydroxyproline index. Children with high indices on admission continued to have them throughout treatment; in the absence of infection levels rose as high as $4 \cdot 5$.

The results indicated that there was a relation between the improvement in the hydroxyproline index and the rate of growth. This was investigated by comparing the average weekly rise or fall in index $(\triangle I / w k$.$) with the change in body weight$ $(\Delta \mathrm{W} / \mathrm{wk}$.$) . The result for marasmic children is$ shown in Fig. 2. The correlation between the two quantities $(r=0.58)$ was statistically significant $(p<0.001)$. The cases of kwashiorkor were not analysed in this way because of the fluctuating oedema which masked the true changes in growth during the first two weeks of treatment.

\section{Discussion}

The diagnosis of kwashiorkor and marasmus is generally made solely on clinical signs, but the clinical signs merge into each other, and the broad term 'protein-calorie malnutrition' has been introduced to cover the whole range of these abnormalities. The expression 'marasmic kwashiorkor' has also been used. If there really are two separate syndromes such diagnoses are valueless as the basis for metabolic and physiological investigations.
The results of this investigation show that certain biochemical tests provide a more objective differential diagnosis. The determination of the serum protein is the simplest of these. When the primary deficiency was one of calories, the serum protein was within the normal range or only slightly depressed, even if the children were very ill, while in the primary protein deficiencies the concentration was always below $5.5 \mathrm{~g} . / 100 \mathrm{ml}$, and much lower in the severe cases.

The amino acid ratio in the plasma also differentiates between the two syndromes. In all cases of kwashiorkor, except one with dark hair (2.9), the amino acid ratio was above $4 \cdot 0$. In marasmus the amino acid ratio was either normal or only slightly raised; in no case was the ratio above $3 \cdot 0$. The abnormal amino acid pattern in kwashiorkor has now been confirmed in various countries, but in Jordan (McLaren, Kamel, and Ayyoub, 1965) and in South Africa (Truswell, Wannenburg, Wittmann, and Hansen, 1966) abnormal ratios were not always found. In both areas the aetiology of kwashiorkor appears to have been different from that in Uganda, for diarrhoea, vomiting, and starvation before admission are important features.

The hydroxyproline excretion has been found to be reduced in malnourished children in Jamaica (Picou et al., 1965), and in India (Anasuya and Rao, 1966), and lowered experimentally in rats (Widdowson and Whitehead, 1966). These present results 
are in general agreement with this, but show that a low excretion of hydroxyproline is not always found in cases of kwashiorkor. In children with severe intercurrent parasitic infestations, the hydroxyproline index tended to be high, and since in these children the colour and texture of the hair were not so severely affected, the clinical signs may have appeared more abruptly than in children with paler hair. Intercurrent infestations may have increased collagen katabolism, and so raised the excretion of hydroxyproline peptides (Smiley and Ziff, 1964). The occurrence of high indices in some of the malnourished children makes the interpretation of this test, in the individual, more difficult than the amino acid ratio or the serum protein. In uncomplicated kwashiorkor, however, the index was always less than $1 \cdot 6$, and it is suggested that children with higher values should be regarded as a special group.

Serial measurements of the hydroxyproline index during treatment provided means of assessing progress more sensitive than changes in the body weight or the serum proteins. Diarrhoea, pyrexia, and other infections which delayed the child's recovery all reduced the index. The most probable explanation is that the index is a measure of some metabolic aspect of growth, retarded by the intercurrent infections. It is not clear why intercurrent illnesses which develop during treatment lower the index, while malaria, hookworm, and roundworm infestations found in some children on admission to the ward are compatible with a relatively high index.

\section{Summary}

Studies were made on 16 children with nutritional marasmus and 36 with kwashiorkor. The children with kwashiorkor were subdivided into those with dark hair and those with pale hair. The clinical state of the dark-haired children was complicated by malaria and intestinal worm infestations.

The amino acid ratio was raised in both groups with kwashiorkor, but only slightly so in the marasmic children. The serum proteins were low in the kwashiorkor, but almost normal in the marasmic cases. The hydroxyproline index was low in the marasmic children and in those with kwashiorkor and pale hair, but it was not so low in those with dark hair. The dark-haired cases of kwashiorkor had very low levels of $\mathrm{Hb}$ and serum protein, but the glucose in their blood was higher and more nearly normal than in that of the palehaired children.

It is suggested that by using the serum protein, the amino acid ratio, and the hydroxyproline index, it is possible to differentiate between calorie deficiency and two types of protein malnutrition.

With successful treatment the hydroxyproline index rose, but if recovery was delayed by intercurrent infections the index fell to levels similar to those found initially. The rate at which the index increased was proportional to the rate of growth.

I would like to thank Mr. G. R. Howells, Mr. J. P. Kiwanuka, and Miss S. D. Ward for conscientious technical assistance; Dr. N. E. Wilkes for the hookworm investigations and Dr. F. Lothe for sickle studies, and Professor R. A. McCance for much useful discussion.

\section{REFERENCES}

Anasuya, A., and Rao, B. S. N. (1966). Urinary excretion of hydroxyproline in kwashiorkor. Lancet, 1, 94

Bonsnes, R. W., and Taussky, H. H. (1945). On the colorimetric determination of creatinine by the Jaffe reaction. $\mathcal{F}$. biol. Chem., 158, 581.

Dacie, J. V., and Lewis, S. M. (1963). Practical Haematology, 3rd ed., pp. 151 and 396. Churchill, London.

Dean, R. F. A., and Jelliffe, D. B. (1960). The diagnosis and treatment of protein-calorie malnutrition. Courrier, 10, 429. , and Swanne, J. (1963). Abbreviated schedule of treatment for severe kwashiorkor, May 1962. F. trop. Pediat., 8, 97.

McLaren, D. S., Kamel, W. W., and Ayyoub, N. (1965). Plasma amino acids and the detection of protein-calorie malnutrition. Amer. F. clin. Nutr., 17, 152.

Marks, V. (1959). An improved glucose-oxidase method for determining blood, C.S.F. and urine glucose levels. Clin. chim. Acta, 4, 395.

Picou, D., Alleyne, G. A. O., Waterlow, J. C., and Seakins, A. (1965). Hydroxyproline and creatinine excretion in proteindepleted infants. Biochem. F., 95, 18p.

Prockop, D. J., and Udenfriend, S. (1960). A specific method for the analysis of hydroxyproline in tissues and urine. Analyt. Biochem., 1, 228.

Rutishauser, I. H. E. (1965). Heights and weights of middle class Baganda children. Lancet, 2, 565.

Smiley, J. D., and Ziff, M. (1964). Urinary hydroxyproline excretion and growth. Physiol. Rev., 44, 30.

Truswell, A. S., Wannenburg, P., Wittmann, W., and Hansen, J. D. L. (1966). Plasma-aminoacids in kwashiorkor. Lancet, 1,1162 .

Varley, H. (1962). Practical Clinical Biochemistry, 3rd ed., p. 494. Heinemann, London.

Whitehead, R. G. (1964). Rapid determination of some plasma aminoacids in subclinical kwashiorkor. Lancet, 1, 250.

(1965). Hydroxyproline creatinine ratio as an index of nutritional status and rate of growth. ibid., 2, 567.

, and Dean, R. F. A. (1964). Serum amino acids in kwashiorkor. II. An abbreviated method of estimation and its application. Amer. F. clin. Nutr., 14, 320.

Widdowson, E. M., and Whitehead, R. G. (1966). Plasma aminoacid ratios and urinary hydroxyproline excretions in rats deficient in protein and calories. Nature (Lond.), 212, 683.

World Health Organisation (1959). Iron deficiency anaemia. Wld Hlth Org. techn. Rep. Ser., No. 182. 